\title{
Incorporation of Small-Group Learning Activities into Biology Lectures to Enhance Learning at a University in Pretoria, South Africa
}

\author{
Liziwe Lizbeth Mugivhisa and Joshua Olawole Olowoyo \\ Department of Biology, Sefako Makgatho Health Sciences University \\ https:// orcid.org/0000-0002-6112-5478 \\ https://orcid.org/0000-0001-8601-091X
}

\begin{abstract}
There have been intense teaching challenges at institutions of higher learning as a result of an increasing range of courses offered to students with diverse backgrounds and levels of preparedness. Lecturers are also faced with a high failure rate and increased retention rates. Student achievement is crucial, and efforts have to be made to adapt and change to methods of teaching that contribute to the better performance of students. Hence, calls have been made for a radical shift from teaching which is teacher-centered to student-centered teaching approaches. The study assessed students' perceptions on the incorporation of active learning in small groups and the impact of the incorporation of smallgroup learning activities into Biology lectures on the performance of the students. Participants showed a preference for small-group learning activities and indicated that incorporating small-group learning activities into lectures should be compulsory. The average mean test marks of 72 Biology students before and after the incorporation of smallgroup learning activities were compared. Results showed that the mean test mark $(52.7 \pm 15.7)$ of the participants was significantly higher after incorporation of small-group learning activities compared to before incorporation $(38.9 \pm 16.4)$, indicating a positive effect $(p<0.05)$ of smallgroup learning activities on student performance. The participants also showed a preference for the incorporation of small-group learning activities into lectures. It is recommended that other factors such as the preparedness of students before assessments be investigated in future studies.
\end{abstract}

Keywords: academic performance; assessments; learning activities; lectures; small groups

\section{Introduction}

Education plays a crucial role in every society and should be given priority as it directs economic and social growth (Diković \& Gergorić, 2020). At institutions of higher learning, education is about complex learning, with large amounts of 
information needing to be organized and remembered (Knight, 2010). An increasing range of courses offered to students with diverse backgrounds and levels of preparedness has resulted in intense teaching challenges at institutions of higher learning (Northedge, 2003). For the majority of students, including those who are successful, the transition to university can be both a great and difficult encounter (Räisänen et al., 2020). In addition to the incorporation of remedial support to struggling students within institutions and teaching programs to address the above-mentioned challenges, there has been a call for a radical shift from the teacher-centered approach of teaching to the student-centered teaching approach (Dema \& Tshering, 2020). In 2017, the Council on Higher Education and the Department of Higher Education and Training jointly convened a national workshop in South Africa to find ways to improve the quality of university teaching so that the success rate of students can be increased.

Lecturers are faced with high failure rates, increased retention rates of students, and a lack of motivation by students (Khan \& Kousar, 2011). Student achievement is critical and lecturers must make efforts to adapt and change to new teaching methods which contribute to the better performance of students. As such, lecturers must consider all the available educational tools with an assortment of technologies and techniques so that students can be provided with the richest possible educational experience (Cherney, 2008; Dema \& Tshering, 2020). Traditional methods of teaching, which include lectures, only need to be revised to accommodate the students of the twenty-first century, who are active learners that might find the lecture method of teaching not beneficial to their engagement (Dema \& Tshering, 2020).

Due to the economic pressures at higher learning institutions, the result is that bigger classes should be taught by a smaller number of lecturers, making lecturebased learning the most effective pedagogy (Killian \& Bastas, 2015). As a result, the teaching activities have mostly concentrated on pedagogies that are teachercentered, with the information being presented to students to mainly cover theoretical knowledge (Manfrin, 2019). In contrast, active learning has recently been introduced, which places students at the center of the learning process as opposed to putting emphasis on the teachers and accepting students as passive learners (Machemer \& Crawford, 2007; Michael, 2006). Universities have made a change in the paradigm of teaching from teacher-centered learning to studentcentered learning (Michael, 2006). According to Muhammad (2016), all learning which is genuine is active and not passive.

In teacher-centered learning, the emphasis is on traditional lectures, where the main role of the students is to listen and take notes. However, in student-centered learning, the main emphasis is on active learning, which may incorporate team-based or cooperative learning to encourage students to be responsible for their education (Machemer \& Crawford, 2007; Manfrin, 2019; Singh et al., 2018). Education should be about learning and not about teaching of the students. Learning should take place when individuals construct their own knowledge individually or socially (Cattaneo, 2017). As such, institutions of education should promote students' social and individual activity in the present society (Diković \& Gergorić, 2020). 
Active learning is defined as any instructional method that results in the engagement of students in the learning process (Demirci, 2017; Hedden et al., 2017; Prince, 2004; Smith \& Cardaciotto, 2011). It is an educational paradigm that focuses on learning instead of teaching (Michael, 2006). The instructional strategies of active learning encompass a wide range of activities that have a common element of students being involved in doing things, interacting with each other, and thinking about the things which they are doing (Demirci, 2017; Eison, 2010; Smith \& Cardaciotto, 2011). According to Felder and Brent (1996), even though many people define active learning as anything which a teacher might ask students to do inside or outside the classroom, a definition that is restricted to in-class activities is more useful. Hence, active learning is defined as anything which is related to the course and which all students in a class are asked to do besides them simply listening, watching, and taking notes (Felder \& Brent, 1996). In active learning, both lecturer and student should have a contribution towards the quality of learning (Zepke, 2013).

Decades of research studies have shown that active-learning approaches consistently promote better learning of students compared to traditional lectures (Burke, 2011; Cavanagh, 2011; Michael, 2006; Owens et al., 2018; Smith \& Cardaciotto, 2011). Research has also shown that students prefer teaching strategies which involve active learning, with the promotion of higher order thinking skills, compared to traditional lectures (Muhammad, 2016). According to Hartikainen et al. (2019), active learning can be described as a wide concept related to learning that is student-centered and includes activities and instructions given by the instructors. Active learning involves deep learning which leads to better retention of knowledge, skills in higher order thinking, engagement, and participation of the students (Bonwell \& Eison, 1991), whilst in the traditional way of teaching, the emphasis is on the recalling of facts and remembering of information (Diković \& Gergorić, 2020). According to Cattaneo (2017), active learning is not new, and its promotion is gaining momentum in academic literature and policies as a viable solution for the enhanced achievement of students.

Active learning is a constructivist perspective of learning in which learners actively construct knowledge that is integrated into the existing experience and knowledge (Hedden et al., 2017). In general, active learning does not include activities which are done by students on their own. Instead, it involves activities which are monitored and organized by the lecturers, making it an instructional approach in which the learning of students is guided (Hartikainen et al., 2019). It is a learning approach in which different activity instructions, such as interactions, deeper processing of information, physical activity, and social collaboration, are given to students (Hartikainen et al., 2019). Active learning helps in that students are kept awake, are together with the lecturer, and can retain more information about the lecture content and learning outcomes (Gǿrtz, 2011). Retention of the concepts by students is increased, especially if students are actively involved with their own learning (Cherney, 2008).

The two major learning theories for active learning are cognitivism and constructivism. In cognitivism, information is transformed into knowledge 
discovery with visualization artefacts that ensure that the problems are solved at the end of the lecture. The cognitive theory puts emphasis on the effects of working together (Abu et al., 1997). According to Hedden et al. (2017), the constructivist approach is a student-centered approach in which learners develop meaning from experience. Students are engaged and required to do meaningful activities; think about what they are doing; and reflect on, analyze, evaluate, and communicate about the information (Manfrin, 2019; Smith \& Cardaciotto, 2011). Learning becomes a constructive process in which the learner builds an internal representation of knowledge. Learning turns into an active process through which meaning is established based on experience. Learning that is student-centered and students being given instructions that make them more active contribute to enhanced achievement in the learning of students (Hartikainen et al., 2019).

The constructivist approach draws on the student creating, instead of simply acquiring, meaning by interacting with the environment. Biggs (1999) stated that in constructive alignment, the teaching is designed in such a way that students engage in learning activities, which increases the chances of them achieving the intended outcomes. According to Oliveira et al. (2006), students' learning is hampered by the exclusive use of lectures which continues in colleges even though it does not encourage interest in the subjects taught (Killian \& Bastas, 2015). The emphasis of the constructivist approach is on higher order thinking, and the engagement of the student is required (Miller \& Metz, 2014). This, in turn, allows students to become information producers instead of information consumers.

Cooperative learning, which can be incorporated into active learning, includes methods of teaching where students learn new academic concepts by working together and assisting each other in small groups organized by the lecturer (Tran, 2014). For cooperative learning to take place, students should be interdependent on one another. The major theoretical perspectives related to cooperative learning are the sociocultural theory of development, and motivational and cognitive theories (Abu et al., 1997). The sociocultural theory of development suggests that students learn when they solve problems beyond their current level of development with the support of their peers or a teacher. During the interaction of the students with each other, perspectives are explained and discussed, leading to a greater understanding of the material to be learned. The motivational theory of cooperative learning emphasizes students' incentive to do academic work, whereas the cognitive theory of cooperative learning emphasizes the effects of working together (Abu et al., 1997).

Several studies have found that groupwork, which is part of cooperative learning, augments academic achievement (Gull \& Shehzad, 2015; McMaster \& Fuchs, 2002; Nichols, 2002). Employers also seek graduates who have skills in teamwork and well-developed interpersonal behavior (Burke, 2011). In addition, Killen (2007) stated that the essence of the motivational perspective is that the rewards of the group encourage individuals to assist each other to achieve (Botelho \& O'Donnell, 2001). Members of the group accomplish their personal goals only when a group is successful (Killen, 2007). Positive interdependence is one of the elements of cooperative learning in which students have the perception that their success or 
failure is dependent on their working together as a group (Abu et al., 1997; Johnson \& Johnson, 2008; Johnson et al., 2014). In a study by Johnson et al. (2006), cooperative learning was found to produce better academic performance than individual and competitive learning. In cooperative learning, learners give each other steppingstones or scaffolds for thinking, which easily explains why students learn from each other when working together.

Learners who are not engaged in learning activities besides watching and listening to the lecturer as with traditional lectures tend to lose concentration and interest in the lectures and end up losing motivation to learn. As a result, calls for teaching which involves more active involvement of students have been made (Owens et al., 2018). Several studies have also been done on the perceptions of students on active learning (Cavanagh, 2011; Machemer \& Crawford, 2007; Miller \& Metz, 2014; Oliveira et al., 2006; Owens et al., 2018), but to the best of our knowledge, a comparison of the assessment marks of students before and after engaging in small-group learning activities have not been made. As such, the research questions for this study were: What are student perceptions on the incorporation of active learning in small groups? and What is the impact of the incorporation of active learning in small groups on the performance of students?

\section{Methods and Procedure}

A quantitative research design was employed for the study through the completion of questionnaires by Biology students to assess their perceptions on the incorporation of small-group learning activities into lectures. The questionnaires were constructed by the researchers. The first questionnaire (Appendix 1) consisted of closed-ended questions and was administered to the participants before the introduction of small-group learning activities in Biology lectures. The questions sought demographic information of the participants, information on which teaching methods students preferred, prior experience with group activities in lectures, student perceptions on the frequency and duration of learning activities, and whether the learning activities would enhance student learning. The second questionnaire (Appendix 2) was administered after the participants had participated in active learning and small-group activities. The questionnaire used a modified Likert scale and consisted of questions that were intended to seek information on the experiences of the participants on the incorporation of learning activities into lectures. A comparison of the experiences of the participants was made between a group of participants who had passed and those who had failed. For ethical considerations, since the marks of the participants were used, and human subjects (students) were involved in the study, ethical clearance was sought from the ethics committee of the School of Science and Technology and the University Ethics Committee. The participants were then asked to complete and sign consent forms.

The Biology course at the university is a semester course, with the first and second semesters covering different topics and content. Only those students who were registered for both semesters of Biology 2 were used as a study sample. In the first semester, lectures were delivered by one of the researchers for about five weeks, without the incorporation of small-group learning activities. In the second semester, for about four weeks, small-group learning activities were incorporated 
into the Biology 2 lectures in the form of mind maps to summarize the lecture content which had been covered each week. The small-group learning activities were incorporated into lectures once a week only and lasted for about 45 minutes each, whereas four traditional lectures were also delivered per week for 45 minutes per lecture.

For the small-group learning activities of each week, participants were randomly divided into groups of about five students per group. To ensure random selection and heterogeneity in the groups, participants were randomly assigned to the groups. To ensure the participation of all the students in each group, each member of the group was given a role and a responsibility during the small-group learning activities and a group leader was selected for each week. Learning activities in the small groups were done on A2-sized papers in the form of mind maps to summarize the content taught in class each week. The learning-activity worksheets were collected after each participant had taken a picture of the worksheets to enable them to use the worksheets as learning tools during examinations.

A total of 126 Biology 2 students, which represented $77.8 \%$ of the whole Biology 2 class, agreed to participate in the completion of the questionnaires for the assessment of the perceptions of students on the incorporation of small-group learning activities into lectures. The first questionnaire was administered at the beginning of semester 2 before the incorporation of small-group learning activities. The sample comprised $29 \%$ male and $71 \%$ female students. The majority of the participants (49\%) were in the age range $18-20$ years, followed by $44.8 \%$ in the age group 21-23 years, with the lowest number of the participants $(5.6 \%)$ being in the 24-27 years age group. In addition, the majority of the participants $(81.4 \%)$ were registered for Biology 2 for the first time. At the end of the second semester, only 41 Biology 2 students, representing $23 \%$ of the class population and having participated in the small-group learning activities, agreed to complete the second questionnaire to determine their experiences on the incorporation of small-group learning activities. A paired sample t-test was used to compare the mean test scores of 72 participants in the first and second semesters before and after the incorporation of the small-group learning activities, respectively $(\mathrm{p}<0.05)$. These 72 participants were those who had attended a minimum of two lectures where there were learning activities, as seen on the class register. Analysis of variance (ANOVA) was used to check if there was any significant difference between the mean test marks of the participants who had engaged in different numbers (frequencies) of the small-group learning activities $(\mathrm{p}<0.05)$.

\section{Results}

Table 1 below shows the results of the questionnaire items which were administered to the participants before the incorporation of small-group learning activities into lectures. 
Table 1: Responses of participants regarding small-group learning activities

\begin{tabular}{|l|c|c|}
\hline \multirow{2}{*}{ Response } & \multicolumn{2}{|l|}{$\begin{array}{l}\text { Percentage of } \\
\text { participants (\%) }\end{array}$} \\
\cline { 2 - 3 } & Yes & No \\
\hline Prior experience in small-group learning activities in lectures. & 43.3 & 56.7 \\
\hline Preference for lectures and small-group learning activities. & 82.4 & 17.6 \\
\hline Preference for working in small groups. & 51.6 & 48.4 \\
\hline $\begin{array}{l}\text { Should small-group learning activities be compulsory in all } \\
\text { course modules? }\end{array}$ & 77.2 & 22.8 \\
\hline $\begin{array}{l}\text { Will small-group learning activities in lectures result in better } \\
\text { academic performance or pass rate? }\end{array}$ & 98.4 & 1.6 \\
\hline
\end{tabular}

Slightly more than half of the participants $(56.7 \%)$ did not have prior experience in small-group learning activities, whereas $43.3 \%$ had been exposed to small-group learning activities. The majority of the participants $(82.4 \%)$ preferred the incorporation of small-group learning activities into lectures, whereas $17.6 \%$ preferred the teaching method of lectures. Furthermore, most of the participants $(77.2 \%)$ responded that small-group learning activities should be compulsory in all course modules, whereas $22.8 \%$ did not want small-group learning activities to be compulsory in all course modules. Lastly, almost all the participants (98.4\%) reported that small-group learning activities would improve their academic performance, with $1.6 \%$ believing that small-group learning activities would not result in an improvement in their academic performance (Table 1).

Participants also had to respond on how frequently small-group learning activities should take place (Figure 1) and how long each small-group learning activity should be (Figure 2). 


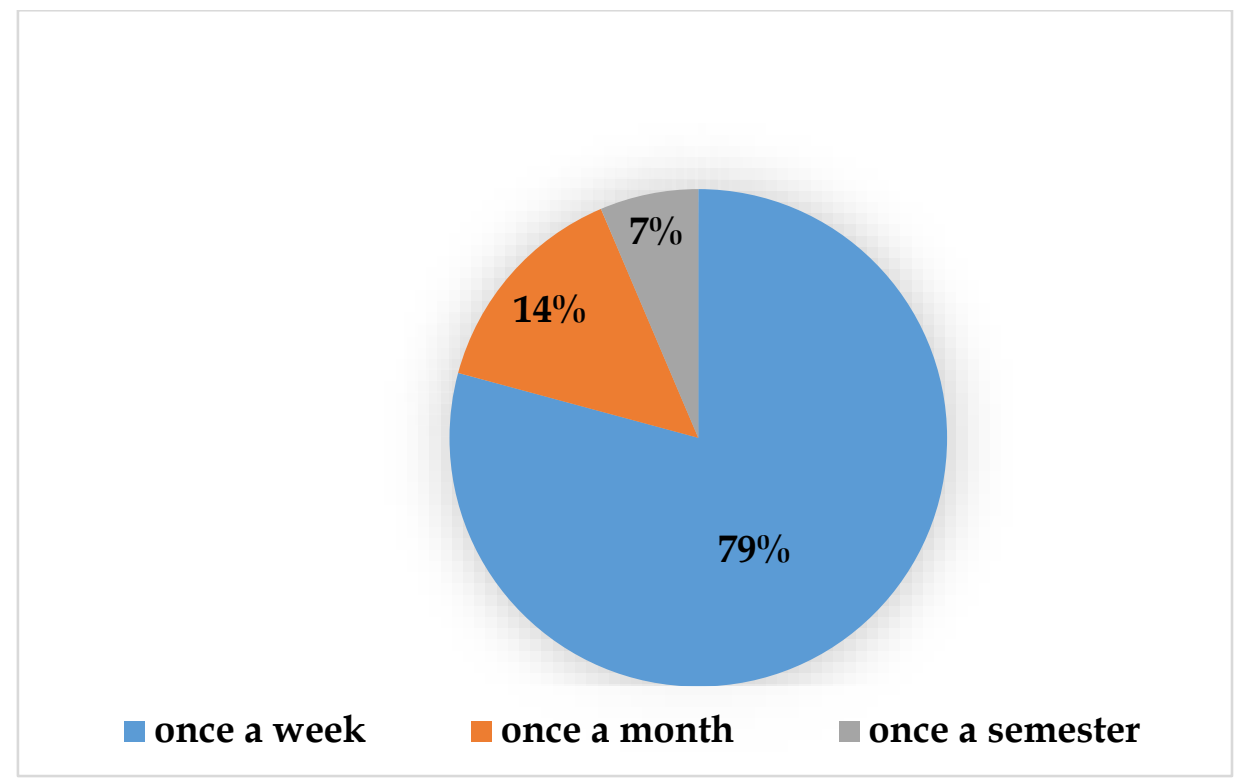

Figure 1: Responses on how frequently small-group learning activities should take place

The majority of the participants (79\%) preferred to have small-group learning activities at least once a week, whereas $14 \%$ and $7 \%$, respectively, preferred smallgroup learning activities once a month and once a semester (Figure 1).

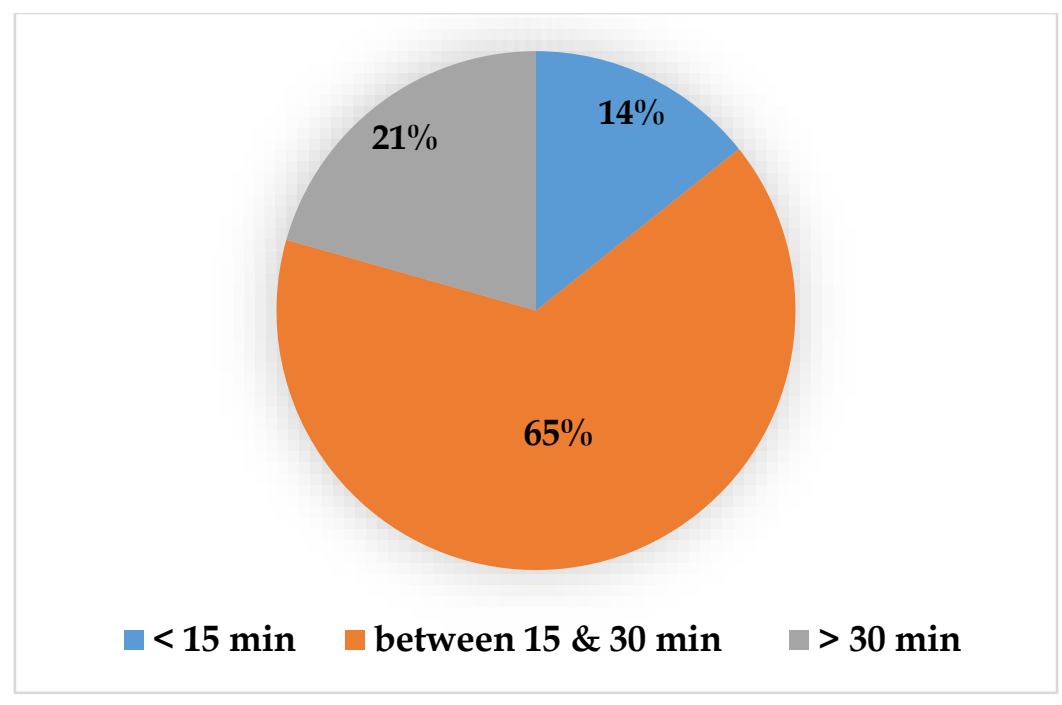

Figure 2: Responses on how long the small-group learning activities should be

With regards to how long the small-group learning activities should be, $65 \%$ of participants preferred to have them for a duration of between 15 and 30 minutes, whereas $21 \%$ preferred them to last for more than 30 minutes (Figure 2). The least number of participants (14\%) preferred small-group learning activities of less than 15 minutes.

The mean and standard deviation of participants' test marks of the first and second semesters were calculated and are depicted in Table 2. 
Table 2: Participant performance in the first and second semesters

\begin{tabular}{|l|c|c|}
\hline Category & $\begin{array}{l}\text { Semester 1 } \\
\text { (before } \\
\text { intervention) (\%) }\end{array}$ & $\begin{array}{l}\text { Semester 2 (after } \\
\text { intervention) (\%) }\end{array}$ \\
\hline Mean test average & $38.9 \pm 16.4$ & $52.7 \pm 15.7$ \\
\hline Minimum mark & 6 & 13 \\
\hline Maximum mark & 82 & 85 \\
\hline Participants who scored above 50\% & 22.2 & 59.7 \\
\hline Participants who scored below 50\% & 77.8 & 40.3 \\
\hline Participants who scored more than $75 \%$ & 4.2 & 8.3 \\
\hline
\end{tabular}

The mean average test mark of $38.9 \% \pm 16.4$ (mean $\% \pm$ standard deviation) for the first semester was significantly lower than the mean average test mark of $52.7 \% \pm 15.7$ for the second semester, after incorporation of the small-group learning activities $(\mathrm{p}<0.05)$ (Table 2). Test marks in the first semester ranged between $6 \%$ and $82 \%$, whereas in the second semester it ranged between $13 \%$ and $85 \%$. Only $22.2 \%$ of the participants scored above the pass mark of $50 \%$ in the first semester, with $59.7 \%$ scoring above the pass mark of $50 \%$ in the second semester. Regarding achieving a distinction (75\%), for the second semester, $8.3 \%$ of participants were able to do so, compared to $4.2 \%$ for the first semester.

Figure 3 shows the test marks of participants engaging in different frequencies of small-group learning activities.

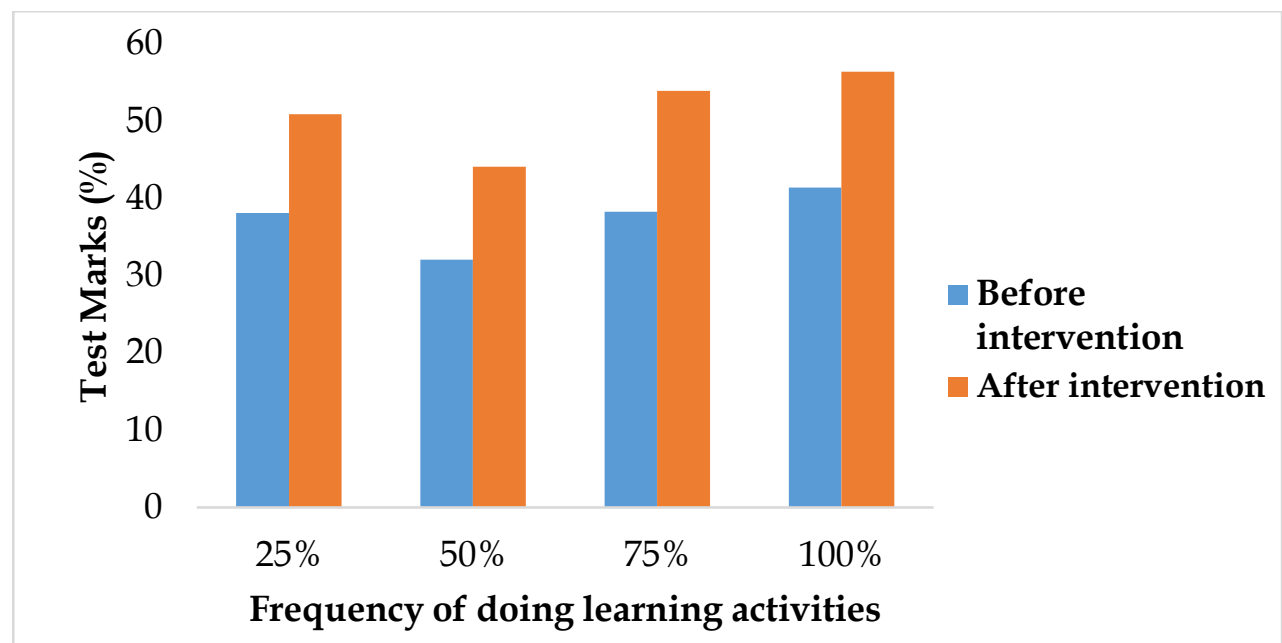

Figure 3: The test marks of participants engaging in different frequencies of smallgroup learning activities

The mean test marks for the second semester were all significantly higher than the mean test marks for the first semester for all the frequencies $(25 \%, 50 \%, 75 \%$, and $100 \%)$ of participant engagement in small-group learning activities $(p<0.05)$. Participants' marks before and after the intervention were also assessed to determine whether the marks had improved or worsened (Figure 4). 


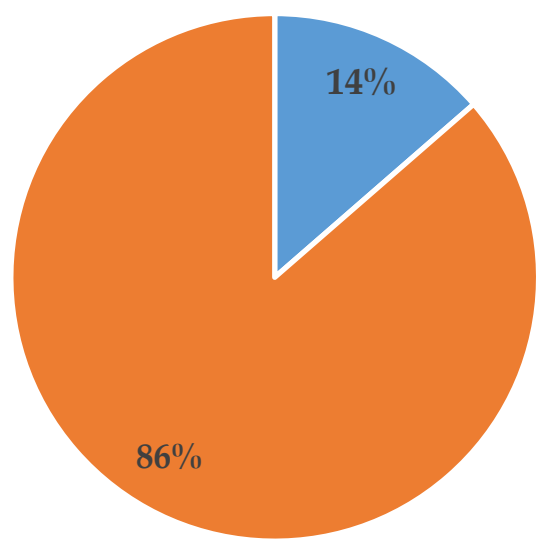

- Marks went down after small groups learning activities

- Marks went up after small groups learning activities

Figure 4: Improvement or worsening of participant marks after intervention of smallgroup learning activities

Figure 4 shows that from the participants who passed in the second semester after the introduction of the small-group learning activities, $14 \%$ had a decline in marks in the second semester compared to $86 \%$ who showed an improvement in the second semester.

Participant responses to the second questionnaire are depicted in Tables 3 and 4 . Table 3 shows the overall responses of all the participants irrespective of whether they passed or failed, whereas Table 4 compares the responses of the participants based on whether they passed or failed. The objective of this questionnaire was to elicit participant responses on the small-group learning activities at the end of the second semester after having engaged in the small-group learning activities.

Table 3: Participant overall responses on small-group learning activities at the end of semester 2

\begin{tabular}{|l|c|c|c|c|c|}
\hline \multirow{2}{*}{ Response } & \multicolumn{4}{|c|}{ Percentage (\%) of participants } \\
\cline { 2 - 6 } & $\begin{array}{l}\text { Strongly } \\
\text { disagree }\end{array}$ & Disagree & Neutral & Agree & $\begin{array}{l}\text { Strongly } \\
\text { agree }\end{array}$ \\
\hline $\begin{array}{l}\text { Group learning activities } \\
\text { increased memory. }\end{array}$ & 0 & 0 & 24.3 & 61 & 14.6 \\
\hline $\begin{array}{l}\text { There was better understanding } \\
\text { of subject content after group } \\
\text { learning activities. }\end{array}$ & 0 & 2.4 & 22 & 64 & 14.6 \\
\hline $\begin{array}{l}\text { Group learning activities are a } \\
\text { good way to learn. }\end{array}$ & 0 & 2.4 & 9.8 & 65.9 & 22 \\
\hline $\begin{array}{l}\text { The group learning activities } \\
\text { were fun and helpful. }\end{array}$ & 4.9 & 7.3 & 19.5 & 46.3 & 22 \\
\hline
\end{tabular}

The majority of the participants (61\%) agreed that group learning activities increased their memory, followed by $24.3 \%$ and $14.6 \%$ who were neutral or strongly agreed, respectively. Only $14.6 \%$ of the participants strongly agreed that 
there was a better understanding of the subject content after having engaged in small-group learning activities, whilst $64 \%$ agreed and $22 \%$ were neutral. The least number of participants $(2.4 \%)$ disagreed that there was a better understanding of subject content after group learning activities. Furthermore, $22 \%$ of participants reported strongly agreeing that small-group learning activities were a good way to learn, with the majority $(66 \%)$ agreeing that group learning activities were a good way to learn. However, $9.8 \%$ reported that they were neutral and $2.4 \%$ disagreed that group learning activities were a good way to learn. The proportion of participants who strongly agreed that the small-group learning activities were fun and helpful was $22 \%$, whilst $46.3 \%$ agreed to this and $19.5 \%$ were neutral. Surprisingly, $7.3 \%$ and $4.9 \%$ of the participants disagreed and strongly disagreed, respectively, with the small-group learning activities being fun and helpful.

Table 4 below also presents participant responses after having engaged in the small-group learning activities. This time, the table is divided into those participants who passed and those who failed in the second semester.

Table 4: A comparison of participant responses between those who passed and those who failed on small-group learning activities at the end of semester 2

\begin{tabular}{|c|c|c|c|c|c|c|c|c|c|c|}
\hline \multirow[t]{2}{*}{ Response } & \multicolumn{5}{|c|}{$\begin{array}{l}\text { Participants who passed after } \\
\text { the small-group learning } \\
\text { activities }\end{array}$} & \multicolumn{5}{|c|}{$\begin{array}{l}\text { Participants who failed after the } \\
\text { small-group learning activities }\end{array}$} \\
\hline & 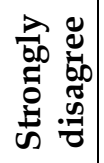 & 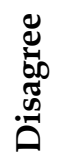 & 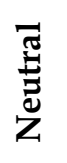 & 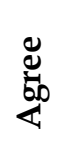 & 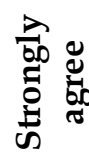 & 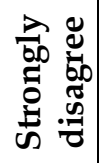 & 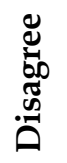 & 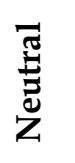 & 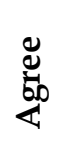 & 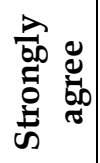 \\
\hline $\begin{array}{l}\text { Learning } \\
\text { activities } \\
\text { increased } \\
\text { memory. }\end{array}$ & 0 & 0 & 19 & 57.2 & 23.8 & 0 & 0 & 30.8 & 61.5 & 7.7 \\
\hline $\begin{array}{l}\text { Better } \\
\text { understanding } \\
\text { after learning } \\
\text { activities. }\end{array}$ & 0 & 0 & 19 & 66.7 & 14.3 & 0 & 7.7 & 23.1 & 53.8 & 15.4 \\
\hline $\begin{array}{l}\text { Learning } \\
\text { activities are a } \\
\text { good way to } \\
\text { learn. }\end{array}$ & 0 & 4.8 & 9.5 & 57.1 & 28.6 & 0 & 0 & 15.4 & 79.2 & 7.7 \\
\hline $\begin{array}{l}\text { Learning } \\
\text { activities } \\
\text { made me } \\
\text { enjoy Biology } \\
\text { more. }\end{array}$ & 4.8 & 9.5 & 9.5 & 52.4 & 23.8 & 7.7 & 0 & 30.8 & 38.5 & 23.1 \\
\hline $\begin{array}{l}\text { Learning } \\
\text { activities will } \\
\text { improve } \\
\text { performance. }\end{array}$ & 0 & 4.8 & 19 & 33.3 & 42.9 & 0 & 0 & 23.1 & 46.2 & 30.8 \\
\hline
\end{tabular}


More of the participants who failed in the second semester felt neutral $(30.8 \%$, $23.1 \%, 15.4 \%, 30.8$, and $23.1 \%$ ) about all the questions which were asked in the questionnaire in the second semester on how they felt after they had engaged in the small-group learning activities compared to the participants who passed in the second semester $(19 \%, 19 \%, 9.5 \%, 9.5 \%$, and 19\%). However, more of the participants who failed $(61.5 \%, 79.2 \%$, and $46.2 \%)$ agreed that the small-group learning activities increased memory, were a good way to learn, and that it would improve performance, respectively, compared to those who passed in the second semester $(57.2 \%, 57.1 \%$, and $33.3 \%$, respectively). In addition, more of the participants who passed strongly agreed $(23.8 \%, 28.6 \%, 23.8 \%$, and $42.9 \%)$ that small-group learning activities increased memory, were a good way to learn, made them enjoy Biology more, and would improve their performance, respectively, compared to those who failed $(7.7 \%, 7.7 \%, 23.1 \%$, and $30.8 \%$, respectively).

\section{Discussion}

The finding of this study that participants had a slight preference for working in groups is in agreement with Oliveira et al. (2006), in whose study the majority of the student participants $(80 \%)$ indicated that the learning activities which included discussion of the problems and group activities were useful to their learning. In a study by Yuretich (2004), students indicated that even though they equally liked lectures, they considered interactions with their peers and lecturers as the most popular features of lectures. Furthermore, in Cavanagh's (2011) study, students valued both traditional lectures and learning tasks in cooperative learning, but valued the varieties of learning activities more. Cooperative learning results in improved participation, understanding, motivation, and better academic performance of students (Gull \& Shehzad, 2015). In addidion, cooperative-learning activities support the understanding of students (Cavanagh, 2011). The engagement with peers supports and scaffolds the learning of the students (Vygotsky, 1997). Individuals tend to learn more when they learn with others than when they learn alone (Michael, 2006). According to Räisänen et al. (2020), in peer learning, students learn through the interaction with each other. In several studies, groupwork has been found to augment academic achievement (Gull \& Shehzad, 2015; McMaster \& Fuchs, 2002; Nichols, 2002).

This study also found that the participating students preferred longer and frequent active-learning sessions and that active learning was useful. This finding correlates with the results of Miller and Metz (2014), which showed that students found active learning useful and preferred to have a larger percentage of the lecture time in Basic Sciences scheduled for learning activities. The results of the present study which showed a significant increase in academic performance when incorporating small-group learning activities are also comparable with the findings of Barrows and Tamblyn (1980). They found that the mean exam scores of students who were taught using active learning were significantly higher than those who were taught in the teacher-centered manner, as with the traditional lectures-only method.

Furthermore, in this study, the majority of participants indicated that the small-group learning activities improved their memory of the subject content. 
These results are comparable with the results of Smith and Cardaciotto (2011), where the majority of the student participants reported more retention of course material. These results are also comparable with those of Towns and Grant (1998). In their study, student participants responded that cooperative-learning activities in lectures contributed to an increase in their learning and comprehension of the content even though some participants felt that learning activities resulted in less content being covered. According to Prince (2004), students tend to remember more content if activities are briefly introduced in lectures.

Active learning is a student-centered pedagogical approach that focuses on the learner and what the learner does in a lecture (Michael, 2006). The finding that the marks of the majority of the participating students increased in the second semester when compared with the first semester is again indicative of the positive impact that the incorporation of the small-group learning activities had on the overall academic performance of the participants. The responses of the participants who failed or passed in the second semester coincided with the responses they gave at the end of the second semester on their experiences of the small-group learning activities.

\section{Conclusion}

It can be concluded that the incorporation of small-group learning activities into lectures has a positive effect on the academic performance of students and hence should be promoted in Biology lectures. The marks of the participants showed an improvement after the incorporation of small-group learning activities compared to when the lectures-only method of teaching was employed. The participants showed a preference for small-group learning activities and suggested that incorporation of small-group learning activities into lectures should be compulsory.

It is recommended that follow-up studies on small-group learning activities should be done on larger groups of students and over an extended period. Other factors, such as the preparedness of students and the presence or absence of other assessments around the time of writing tests, which can have an impact on the performance of the students, should also be investigated. The impact of other learning activities on the academic performance of students, such as answering questions or taking part in class group discussions, should also be explored. This should not include the summarizing of lecture content into mind maps. In addition, more studies should be carried out with other subjects and different levels of study.

\section{Acknowledgments}

The authors would like to sincerely thank all the students who took part in the study by completing the questionnaires and taking part in the small-group learning activities. The authors would also like to thank the Teaching Advancement Fellowships Programme (TAU) - 2018/2019, an initiative of the Higher Education Learning \& Teaching Association of Southern Africa (HELTASA), for granting one of the authors an opportunity to take part in the program and hence carrying out the study. 


\section{References}

Abu, R. B., Pendidikan, F. P., \& Flowers, J. (1997). The effects of cooperative learning methods on achievement, retention and attitudes of Home Economics students in North Carolina. Journal of Career and Technical Education, 13(2), 16-22. https:// files.eric.ed.gov/fulltext/EJ543960.pdf

Biggs, J. (1999). What the student does: Teaching for enhanced learning. Higher Education Research and Development, 18(1), 57-75. https://doi.org/10.1080/07294360.2012.642839

Barrows, H. S., \& Tamblyn, R. M. (1980). Problem-based learning: An approach to medical education. Springer.

Bonwell, C. C., \& Eison, J. A. (1991). Active learning: Creating excitement in the classroom (Rep. no. 1). George Washington University, ASHEERIC Higher Education.

Botelho, M. G. \& O'Donnell, D. O. (2001). Assessment of the use of problem-orientated, small-group discussion for learning of a fixed prosthodontic, simulation laboratory course. British Dental Journal, 191(11), 630-636. https://doi.org/10.1038/sj.bdj.4801253a

Burke, A. (2011). Group work: How to use groups effectively. The Journal of Effective Teaching, 11(2), 87-95. https://uncw.edu/jet/articles/vol11_2/burke.pdf

Cattaneo, K. H. (2017). Telling active learning pedagogies apart: From theory to practice. Journal of New Approaches in Educational Research, 6(2), 144-152. https:// doi.org/10.7821/naer.2017.7.237

Cavanagh, M. (2011). Students' experiences of active engagement through cooperative learning activities in lectures. Active Learning in Higher Education, 12(1), 23-33. https://doi.org/10.1177/1469787410387724

Cherney, I. D. (2008). The effects of active learning on students' memories for course content. Active Learning in Higher Education, 9(2), 152-171. https:// doi.org/10.1177/1469787408090841

Dema, K., \& Tshering, K. (2020). The effects of active learning approach in teaching and learning science: A case of one of the primary schools in Bhutan. International Research Journal for Quality in Education, 7(1). https://www.researchgate.net/publication/339641177_The_effects_of_active_le arning_approach_in_teaching_and_learning_science_A_case_of_one_of_the_pri mary_schools_in_Bhutan

Demirci, C. (2017). The effect of active learning approach on attitudes of 7th grade students. International Journal of Instruction, 10(4), 129-144. https://doi.org/10.12973/iji.2017.1048a

Diković, M., \& Gergorić, T. (2020). Teachers' assessment of active learning in teaching Nature and Society. Economic Research | Ekonomska Istraživanja, 33(1), 1265-1279. https://doi.org/10.1080/1331677X.2020.1728563

Eison, J. (2010). Using active learning instructional strategies to create excitement and enhance learning. University of South Florida. file:///C:/Users/Lenovo/Downloads/UsingActiveLearningInstructionalStrate giestoCreateExcitementandEnhanceLearningEisen-Handout.pdf

Felder, R. M., \& Brent, R. (1996). Navigating the bumpy road to student-centered instruction. College Teaching, 44(2), 43-47. https:// doi.org/10.1080/87567555.1996.9933425

Gǿrtz, I. (2011). Active learning in large classes. Proceedings of the 7th International CDIO Conference, Technical University of Denmark, Copenhagen, June 20-23, 2011.

Gull, F., \& Shehzad, S. (2015). Effects of cooperative learning on students' academic achievement. Journal of Education and Learning, 9(3), 246-255.

Hartikainen, S., Rintala, H., Pylväs, L., \& Nokelainen, P. (2019). The concept of active learning and the measurement of learning outcomes: A review of research in 
engineering higher education. Education Sciences, 9(4), 276. https:// doi.org/10.3390/educsci9040276

Hedden, M. K., Worthy, R., Akins, E., Slinger-Friedman, V., \& Paul, R. C. (2017). Teaching sustainability using an active learning constructive approach: Discipline-specific case studies in higher education. Sustainability, 9(8), 1320. https://doi.org/10.3390/su9081320

Johnson, D. W., Johnson, R. T., \& Smith, K. A. (2006). Active learning: Cooperation in the university classroom ( $3^{\text {rd }}$ ed.). Interaction.

Johnson, D. W., \& Johnson, R. T. (2008). Social interdependence theory and cooperative learning: The teacher's role. In R. M. Gillies, A. Ashman, \& J. Terwel (Eds.), Teacher's role in implementing cooperative learning in the classroom (pp. 9-37). Springer. https://doi.org/10.1007/978-0-387-70892-8_1

Johnson, D. W., Johnson, R. T., \& Smith, K. A. (2014). Cooperative learning: Improving university instruction by basing practice on validated theory. Journal of Excellence in College Teaching, 25, 85-118. https://www.researchgate.net/publication/284471328_Cooperative_Learning_I mproving_university_instruction_by_basing_practice_on_validated_theory

Khan, Y. A., \& Kousar, S. (2011). Factors influencing academic failure of university students. Conference: 8th International Conference on Recent Advances in Statistics At: Lahore, Pakistan. https://doi.org/10.13140/2.1.2900.7360

Killen, R. (2007). Teaching strategies for outcomes-based education (2 $2^{\text {nd }}$ ed.). Social Science Press.

Killian, M., \& Bastas, H. (2015). The effects of an active learning strategy on students' attitudes and students' performances in introductory sociology classes. Journal of the Scholarship of Teaching and Learning, 15(3), 53-67. https://doi.org/10.14434/josotl.v15i3.12960

Knight, P. T. (2010). Complexity and curriculum: A process approach to curriculummaking. Teaching in Higher Education, 6(3), 369-381. https://doi.org/10.1080/13562510120061223

Machemer, P. L., \& Crawford, P. (2007). Student perceptions of active learning in a large cross-disciplinary classroom. Active Learning in Higher Education, 8(1), 9-30. https:// doi.org/10.1177/1469787407074008

Manfrin, A. (2019). Students and faculty perception of active learning: A case study. Student Engagement in Higher Education Journal, 3(1). https://www.researchgate.net/publication/337243204_Students_and_faculty_p erception_of_Active_Learning_a_case_study

McMaster, K., \& Fuchs, D. (2002). Effects of cooperative learning on the academic achievement of students with learning disabilities: An update of TateyamaSniezek's reviews. Learning Disabilities Research Practice, 17(2), 107-117. https://doi.org/10.1111/1540-5826.00037

Michael, J. (2006). Where's the evidence that active learning works? Advanced Physiology Education, 30, 159-167. https://doi.org/10.1152/advan.00053.2006

Miller, C. J., \& Metz, M. J. (2014). A comparison of professional-level faculty and student perceptions of active learning: Its current use, effectiveness and barriers. Advanced Physiology Education, 38, 246-252.

Muhammad, H. A. (2016). Active learning \& teaching: Challenges $\mathcal{E}$ tips for teachers. $7^{\text {th }}$ International Visible Conference of Educational Studies \& Applied Linguistics, Erbil, Kurdistan, Iraq, 23-24 April 2016.

Nichols, J. (2002). The effects of cooperative learning on student achievement and motivation in a high school Geometry class. Contemporary Educational Psychology, 21(4), 467-476. https://doi.org/10.1006/ceps.1996.0031

Northedge, A. (2003). Rethinking teaching in the context of diversity. Teaching in Higher Education, 8(1), 17-32. https://doi.org/10.1080/1356251032000052302 
Oliveira, P. C., Oliveira, C. G., De Souza, F., \& Costa, N. (2006). Teaching strategies to promote active learning in higher education. In A. Méndez-Vilas, A. Solano Martin, J. A. Mesa González, \& J. Mesa González (Eds.), Current developments in technology-assisted education (pp. 636-640). Formatex.

Owens, M. T., Trujillo, G., Seidel, S. B., Harrison, C. D., Farrar, K. M., Benton, H. P., Blair, J. R., Boyer, K. E., Breckler, J. L., Burrus, L. W., Byrd, D. T., Caporale, N., Carpenter, E. J., Chan, Y-H. M., Chen, J. C., Chen, L., Chen, L. H., Chu, D. S., Cochlan, W. P., Crook, R. J., et al. (2018). Collectively improving our teaching: Attempting Biology Department-wide professional development in scientific teaching. CBE Life Sciences Education, 17(1). https:// doi.org/10.1187/cbe.17-06-0106

Prince, M. (2004). Does active learning work? A review of the research. Journal of Engineering Education, 93(3), 223-231. https://www.engr.ncsu.edu/wpcontent/uploads/drive/1smSpn4AiHSh8z7a0MHDBwhb_JhcoLQmI/2004Prince_AL.pdf

Räisänen, M., Postareff, L., Mattsson, M., \& Lindblom-Ylänne, S. (2020). Study-related exhaustion: First-year students' use of self-regulation of learning and peer learning and perceived value of peer support. Active Learning in Higher Education, 21(3), 173-188. https://doi.org/10.1177/1469787418798517

Singh, K., Mahajan, R., Gupta, P., \& Singh, T. (2018). Flipped classroom: A concept for engaging medical students in learning. Indian Pediatrics, 55(6), 507-512. https://doi.org/10.1007/s13312-018-1342-0

Smith, C., \& Cardaciotto, L. (2011). Is active learning like broccoli? Student perceptions of active learning in large lecture classes. Journal of the Scholarship of Teaching and Learning, 11(1), 53-61. https://teachingcommons.yorku.ca/wpcontent/uploads/2017/11/Is-active-learning-like-broccoli.pdf

Towns, M. H., \& Grant, E. R. (1998). I believe I will go out of this class actually knowing something: Cooperative learning activities in Physical Chemistry. Journal of Research in Science Teaching, 34(8), 819-835. https://doi.org/10.1002/(SICI)10982736(199710)34:8<819::AID- TEA5>3.0.CO;2-Y

Tran, V. D. (2014). The effects of cooperative learning on the academic achievement and knowledge retention. International Journal of Higher Education, 3(2), 131-140. https://doi.org/10.5430/ijhe.v3n2p131

Vygotsky, L. S. (1997). Interaction between learning and development (1978). In M. Gauvin, \& M. Cole (Eds.), From mind and society: Readings on the development of children (pp. 7991). Freeman and Company; Harvard University Press.

Yuretich, R. F. (2004). Encouraging critical thinking: Measuring skills in large introductory science classes. Journal of College Science Teaching, 33(3), 40-46.

Zepke, N. (2013). Threshold concepts and student engagement: Revisiting pedagogical content knowledge. Active Learning in Higher Education, 14(2), 97-107. https://doi.org/10.1177/1469787413481127 


\section{Appendix 1}

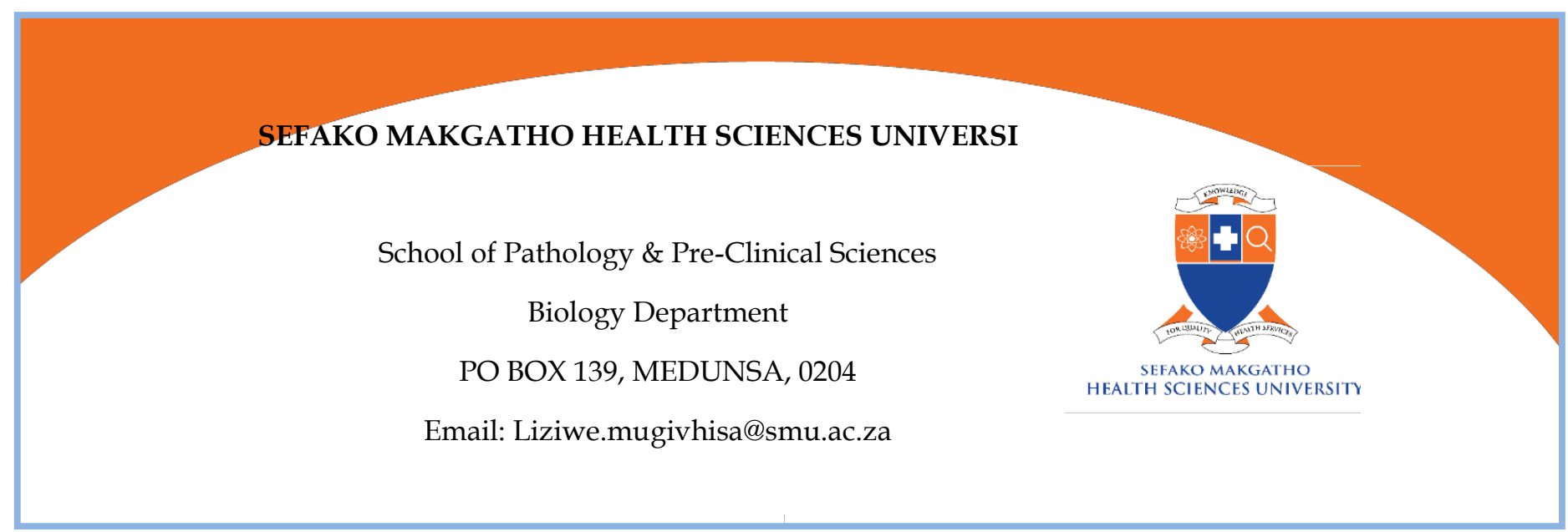

Incorporation of learning activities in small groups into the Biology lectures to enhance learning at a university in Pretoria, South Africa

Definition of learning activity:

"In short, active learning requires students to do meaningful learning activities and think about what they are doing". Prince (2004, p. 223).

1. Age

2. Gender

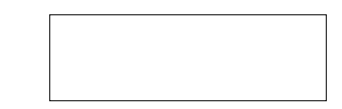

\begin{tabular}{|l|l|}
\hline Male & Female \\
\hline
\end{tabular}

3. Are you doing Biology for the first time?

\begin{tabular}{|l|l|}
\hline Yes & No \\
\hline
\end{tabular}

4. Do you ever enthusiastically answer questions in the lectures?

\begin{tabular}{|l|l|}
\hline Yes & No \\
\hline
\end{tabular}

5. In class are you able to concentrate for the whole class?

\begin{tabular}{|l|l|}
\hline Yes & No \\
\hline
\end{tabular}

6. If "no" after how long does your concentration go down

\begin{tabular}{|l|l|l|}
\hline $\begin{array}{l}\text { After 10 } \\
\text { min }\end{array}$ & $\begin{array}{l}\text { After 15 } \\
\text { min }\end{array}$ & $\begin{array}{l}\text { More than } \\
15 \text { min }\end{array}$ \\
\hline
\end{tabular}


7. Which method of teaching do you prefer?

\begin{tabular}{|l|l|}
\hline Lectures only & $\begin{array}{l}\text { Lectures \& activities / } \\
\text { discussions }\end{array}$ \\
\hline
\end{tabular}

8. Have you ever experienced any teaching method which incorporated learning activities in any

\begin{tabular}{|l|l|}
\hline Yes & No \\
\hline
\end{tabular}
of your lectures?

9. When given learning activities would you prefer to work individually or in a group?

\begin{tabular}{|l|l|}
\hline Individually & In a group \\
\hline
\end{tabular}

10. When given learning activities how often would you prefer to do the learning activities?

11. How long do you think the learning activities should be?

\begin{tabular}{|l|l|l|}
\hline$<15$ min & $\begin{array}{l}\text { Between 15 \& 30 } \\
\text { min }\end{array}$ & $>30$ min \\
\hline
\end{tabular}

12. Do you think learning activities in lectures should be compulsory in all course modules?

\begin{tabular}{|l|l|}
\hline Yes & No \\
\hline
\end{tabular}

13. Do you think learning activities in lectures would enhance the learning of the students or result in better performance / pass rate?

\begin{tabular}{|l|l|}
\hline Yes & No \\
\hline
\end{tabular}


Appendix 2

SEFAKO MAKGATHO HEALTH SCIENCES

UNIVERSITY

School of Pathology \& Pre-Clinical Sciences

Biology Department

PO BOX 139, MEDUNSA, 0204 HEALTH SCIENCES UNIVERSITY

Email: Liziwe.mugivhisa@smu.ac.za

Incorporation of

learning activities in small groups into the Biology lectures to enhance

learning at a university in Pretoria, South Africa

Answer the questions by ticking in the blocks which best describe your responses.

\begin{tabular}{|l|l|l|l|l|l|}
\hline & $\begin{array}{c}\text { Strongly } \\
\text { disagree } \\
(1)\end{array}$ & $\begin{array}{l}\text { Disagree } \\
(2)\end{array}$ & Neutral & $\begin{array}{c}\text { Agree } \\
(3)\end{array}$ & $\begin{array}{c}\text { Strongly } \\
\text { agree } \\
(4)\end{array}$ \\
\hline $\begin{array}{l}\text { The learning activities in small } \\
\text { groups contributed to me } \\
\text { remembering the course content } \\
\text { better. }\end{array}$ & & & & & \\
\hline $\begin{array}{l}\text { I gained better understanding of } \\
\text { the course content after doing the } \\
\text { learning activities in small } \\
\text { groups. }\end{array}$ & & & & & \\
\hline $\begin{array}{l}\text { The learning activities in small } \\
\text { groups were a good way to learn } \\
\text { about the topics. }\end{array}$ & & & & & \\
\hline $\begin{array}{l}\text { Learning activities in small } \\
\text { groups made me enjoy doing } \\
\text { Biology more }\end{array}$ & & & & & \\
\hline $\begin{array}{l}\text { I think learning activities will } \\
\text { contribute to me performing } \\
\text { better in exams }\end{array}$ & & & & & \\
\hline
\end{tabular}

